\title{
Excitation functions of proton induced reactions of some radioisotopes used in medicine
}

https://doi.org/10.1515/chem-2018-0085

received February 15, 2018; accepted April 18, 2018.

Abstract: The main purpose of this study is the investigation of a cross section of proton induced nuclear reactions. The excitation functions of the reactions: ${ }^{56} \mathrm{Fe}(\mathrm{p}, 2 \mathrm{n}){ }^{55} \mathrm{Co} \quad{ }^{58} \mathrm{Fe}(\mathrm{p}, 2 \mathrm{n}){ }^{57} \mathrm{Co},{ }^{111} \mathrm{Cd}(\mathrm{p}, 2 \mathrm{n}){ }^{110} \mathrm{In}$, ${ }^{112} \mathrm{Cd}(\mathrm{p}, 2 \mathrm{n}){ }^{111} \mathrm{In},{ }^{125} \mathrm{Te}(\mathrm{p}, 2 \mathrm{n}){ }^{124} \mathrm{I},{ }^{126} \mathrm{Te}(\mathrm{p}, 2 \mathrm{n}){ }^{125} \mathrm{I},{ }^{68} \mathrm{Zn}(\mathrm{p}, 2 \mathrm{n}){ }^{67} \mathrm{Ga}$ were investigated. These reactions were studied as the resulting radioisotopes are used in medical applications. Theoretical excitation functions have been calculated with TALYS 1.6 nuclear reaction simulation code. The calculated excitation functions are compared with the experimental data.

Keywords: Excitation functions; proton induced; TALYS 1.6 nuclear reaction simulation code.

PACS: 13.85.Lg, 92.20.Td, 52.59.-f

\section{Introduction}

In nuclear medicine radionuclides are used for a variety of useful applications, such as diagnosis, therapy, prevention of many serious ailments and research to evaluate metabolic, physiologic and pathologic conditions of the human body. The successful production and usage of these radionuclides extends to oncology, cardiology and even psychiatry by imaging procedures where information about the function of every major organ/ tissue of the human body can be generated. A large number of radionuclides used in nuclear medicine

*Corresponding author: Susan Shukur Noori, Süleyman Demirel University, Sciences \& Arts Faculty, Isparta-Turkey; Kirkuk University, College of Science, Kirkuk-Iraq, E-mail: suzan_nuclear@yahoo.com İskender Akkurt: Süleyman Demirel University, Sciences \& Arts Faculty, Isparta-Turkey

Nurdan Karpuz Demir: Amasya University, Sabuncuoğlu Şerefeddin Vocational School of Health Services, Amasya, Turkey are produced in cyclotrons, accelerators or in nuclear reactors, and production is an important and constantly evolving issue. In addition to this different radionuclides play significant roles in technological applications of importance to our daily life as well for scientific research $[1,2]$. Production cross sections for charged particles especially nuclear reactions on metals which are induced by protons are important in medical radioisotopes production [3,4]. To optimize the production routes, the charged particle induced cross-sections are desired. For the optimization of the radioisotope produced, a full knowledge of the excitation function is necessary, which helps to maximize the yield of the desired product and to minimize the radioactive impurities [5]. At present the Positron Emission Tomography (PET) imaging technique is widely used for planning, early diagnosis of cancer and evaluation of the treatment response in patients with cancer, this imaging technique is used to studies diseases of heart, brain, thyroid etc. [6]. For a variety of the radioisotopes used in the PET technique, the excitation functions of proton induced by nuclear reactions were calculated using a Monte Carlo nuclear reaction simulation code TALYS 1.6 [7]. The obtained results were compared with the experimental data existing in the EXFOR [8].

\section{Software and methods}

Nuclear medicine uses a trace amount of radioactive substances called radiotracers that are typically injected into the bloodstream, inhaled or swallowed to provide diagnostic information that gives accurate and immediate diagnosis regarding the functioning of a specific organ in the human body or to treat a disease. It is used to form images of the bones, thyroid, liver, heart, and many other organs and also helps in treating diseased organs and certain types of cancer tumours.

Calculations based on nuclear reaction models play an important role in the development of reaction cross sections [6]. In this work the excitation Function calculations were carried out with nuclear reaction 
Table 1: Decay data of the product radioisotopes $[1,10,11]$ and the calculated E-threshold energy and Q-value.

\begin{tabular}{|c|c|c|c|c|c|c|}
\hline Reaction product & Half life & Mode of decay (\%) & $E_{\mathrm{v}}(\mathrm{keV})$ & $I_{\gamma}(\%)$ & E-threshold MeV) & Q-value (MeV) \\
\hline \multirow[t]{3}{*}{${ }^{55} \mathrm{Co}$} & $17.6 \mathrm{~h}$ & $\beta^{+}(77)$ & 477.2 & 20.2 & 15.7087 & -15.4308 \\
\hline & & EC (23) & 931.1 & 75.0 & & \\
\hline & & & 1408.5 & 16.9 & & \\
\hline \multirow[t]{2}{*}{${ }^{57} \mathrm{Co}$} & $271.8 \mathrm{~d}$ & $\mathrm{EC}(100)$ & 122.06 & 85.6 & 11.8660 & -11.6632 \\
\hline & & & 136.5 & 10.68 & & \\
\hline${ }^{110} \mathrm{In}$ & $69.1 \mathrm{~m}$ & EC (100) & 657.76 & 98.0 & 11.7417 & -11.636 \\
\hline \multirow[t]{2}{*}{${ }^{111} \mathrm{In}$} & $2.83 \mathrm{~d}$ & $\mathrm{EC}(100)$ & 171.28 & 90.0 & 11.1379 & -11.0386 \\
\hline & & & 245.39 & 94.0 & & \\
\hline \multirow[t]{2}{*}{124} & $4.18 \mathrm{~d}$ & $\beta^{+}(22)$ & 602.7 & 60.5 & 10.5957 & -10.5109 \\
\hline & & EC (78) & 1691.0 & 10.4 & & \\
\hline 125 & $60.1 \mathrm{~d}$ & EC (100) & 35.5 & 6.7 & 10.1625 & -10.0818 \\
\hline \multirow[t]{2}{*}{${ }^{67} \mathrm{Ga}$} & $3.26 \mathrm{~d}$ & $\mathrm{EC}(100)$ & 93.31 & 39.2 & 12.1593 & -11.9816 \\
\hline & & & 300.2 & 16.8 & & \\
\hline
\end{tabular}

simulation code TALYS1.6. TALYS is a Monte Carlo code. TALYS was initially develpoed in 1998, when it was decided to implement the combined knowledge of nuclear reactions into one single software package which integrates the pre-equilibrium, direct, optical model, statistical and fission nuclear reaction models and for all the open reaction channels it gives prediction in one calculation scheme.

The TALYS code is a nuclear reaction computer program which simulates basically all types of nuclear reactions, it runs on Linux operation system and is written in the FORTRAN programming language. One of the possible outcomes of using a Monte Carlo method for nuclear data evaluation is that a series of correlations can be extracted from the previous results. The objective and vision of its construction was to provide a complete and accurate simulation of nuclear reactions that involve neutrons, photons, protons, deuterons, tritons, 3He, and alpha particles in the $1 \mathrm{keV}-200 \mathrm{MeV}$ energy range, with some exceptions. The code's data was based on the reference input parameter library through an optimal combination of reliable nuclear models, resilience and ease of use [7,9].

The theory of excitation functions for production of medical radioisotopes are obtained with proton induced reactions $(\mathrm{p}, 2 \mathrm{n})$ for some radioisotopes used in medicine that are important for the development of improved nuclear reaction theory and for many medical applications were calculated by use TALYS 1.6 code. The calculation for nuclear reactions, are usually employed in cases where there is a shortage of experimental data or there are other controversies. Moreover, it ensures the internal consistency of the data, and also allows us to predict and extrapolate the experimental data [3].
Ethical approval: The conducted research is not related to either human or animals use.

\section{Result and Discussions}

Excitation functions via proton induced reactions are important for many medical applications and for development of improved nuclear reaction theory. In the present work, the calculated excitation functions for production of medical radioisotopes with proton induced nuclear reactions ${ }^{56} \mathrm{Fe}(\mathrm{p}, 2 \mathrm{n}){ }^{55} \mathrm{Co},{ }^{58} \mathrm{Fe}(\mathrm{p}, 2 \mathrm{n}){ }^{57} \mathrm{Co}$, ${ }^{111} \mathrm{Cd}(\mathrm{p}, 2 \mathrm{n}){ }^{110} \mathrm{In}, \quad{ }^{112} \mathrm{Cd}(\mathrm{p}, 2 \mathrm{n}){ }^{111} \mathrm{In}, \quad{ }^{125} \mathrm{Te}(\mathrm{p}, 2 \mathrm{n}){ }^{124} \mathrm{I}$, ${ }^{126} \mathrm{Te}(\mathrm{p}, 2 \mathrm{n}){ }^{125} \mathrm{I},{ }^{68} \mathrm{Zn}(\mathrm{p}, 2 \mathrm{n}){ }^{67} \mathrm{Ga}$ are carried out using Monte Carlo simulation code TALYS 1.6. The calculated results are shown in Figures 1-7 together with the experimental data existing in the EXFOR library. Additionally, the halflife, and decay data of produced radioisotopes in this study are shown in Table 1, as well as the calculated the threshold energy (E-threshold) and the Q-value of the reactions calculated by the TALYS code.

\subsection{Cobalt Radioisotopes Production}

${ }^{55} \mathrm{Co}$ and ${ }^{57} \mathrm{Co}$ are two important radioisotopes of cobalt. The first one is used in Positron Emission Tomography (PET) to detect of cancer and other diseases such as cardiac and cerebral disease. In the late 1990s the most important application of ${ }^{55} \mathrm{Co}$ was developed, in the field of imaging neuronal damage from a stroke or traumatic injury. ${ }^{57} \mathrm{Co}$ is applied in various studies as a radioactive tracer. ${ }^{57} \mathrm{Co}$ with Vitamin B 12 (albumin) labeled is used in diagnostic kits to study anemia, ${ }^{57} \mathrm{Co}$ is a useful 
Mossbauer radioisotope, its use as a calibration standard for gamma-spectrometers and single photon emission tomography (SPECT) are its most general use. It is also used in medicine to help detect cancerous tumors and as a component in medical equipment studying the chemical properties of various materials or testing the response of Gamma cameras [12-15]. By using TALYS 1.6 code, the excitation function of proton-induced were calculated for the reactions ${ }^{56} \mathrm{Fe}(\mathrm{p}, 2 \mathrm{n}){ }^{55} \mathrm{Co},{ }^{58} \mathrm{Fe}(\mathrm{p}, 2 \mathrm{n}){ }^{57} \mathrm{Co}$ and compared with the available experimental data in EXFOR library as shown in Figures 1 and 2 at proton energies up to $50 \mathrm{MeV}$. As noted the best energy range for production is from 18 to $35 \mathrm{MeV}$ and from 14 to $28 \mathrm{MeV}$ for produced radioisotopes ${ }^{55} \mathrm{Co}$ and ${ }^{57} \mathrm{Co}$ respectively.

\subsection{Indium Radioisotopes Production}

${ }^{110}$ In and ${ }^{111}$ In are indium's radioisotopes used in specialized diagnostic applications, e.g. brain studies, infection and colon transit studies. They are used as a radioactive tracer in nuclear medicine in a chelate form, as a cerebrospinal fluid tracer. It also used as a white blood cell labeling agent (also called indium-111 white blood cell scan) and as an antibody label. Indium-111 oxine is also useful for labelling blood cell components. Other applications like labelling of platelets for thrombus detection and labelled leukocytes for localization of the inflammation, also leukocyte kinetics. Used with Ga-67 for soft tissue infection detection and osteomyelitis detection, white blood cell imaging (also called indium-111 white blood cell scan), cellular dosimetry, myocardial scans, treatment of leukemia, imaging tumors [20-24]. Excitation functions of the proton-induced at energies up to $50 \mathrm{MeV}$ activities on ${ }^{111} \mathrm{Cd}$ and ${ }^{112} \mathrm{Cd}$ via the two reactions ${ }^{111} \mathrm{Cd}(\mathrm{p}, 2 \mathrm{n}){ }^{110} \mathrm{In}$, ${ }^{112} \mathrm{Cd}(\mathrm{p}, 2 \mathrm{n})^{111}$ In were calculated by TALYS 1.6 code to obtained radioisotopes ${ }^{110} \mathrm{In}$ and ${ }^{111} \mathrm{In}$ respectively, the comparison of experimental and calculated results of reactions ${ }^{111} \mathrm{Cd}(\mathrm{p}, 2 \mathrm{n}){ }^{110} \mathrm{In},{ }^{112} \mathrm{Cd}(\mathrm{p}, 2 \mathrm{n}){ }^{111} \mathrm{In}$ are represented in Figures 3 and 4. The best production range for each of ${ }^{110} \mathrm{In}$ and ${ }^{111} \mathrm{In}$ is $12-30 \mathrm{MeV}$.

\section{3 lodine Radioisotopes Production}

${ }^{124} \mathrm{I}$ is the only long-life positron emitter isotope of iodine, which can be used both for diagnosis and therapy and remains the most frequently used radionuclides for thyroid imaging. ${ }^{124} \mathrm{I}$ used in PET applications and it is attracting increasing interest for long-term clinical studies. With

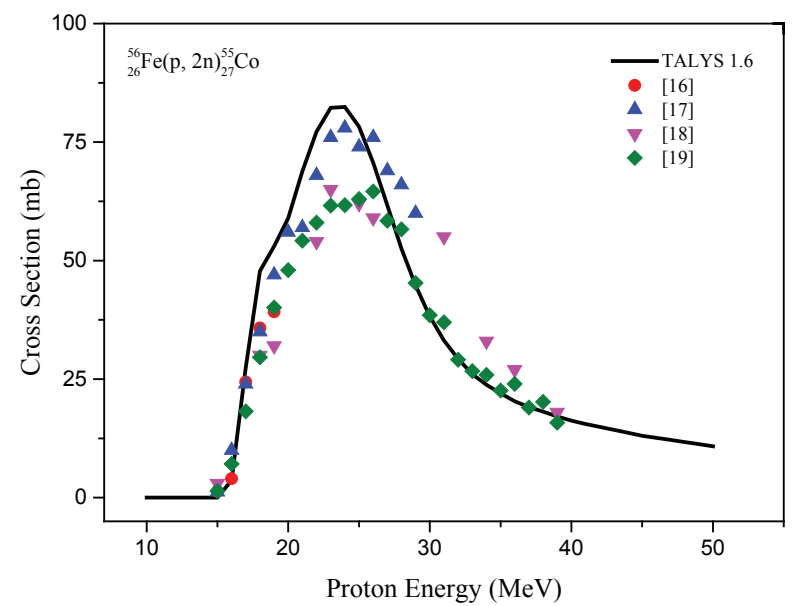

Figure 1: Excitation function of the ${ }^{56} \mathrm{Fe}(\mathrm{p}, 2 \mathrm{n})^{55} \mathrm{Co}$ nuclear reaction.

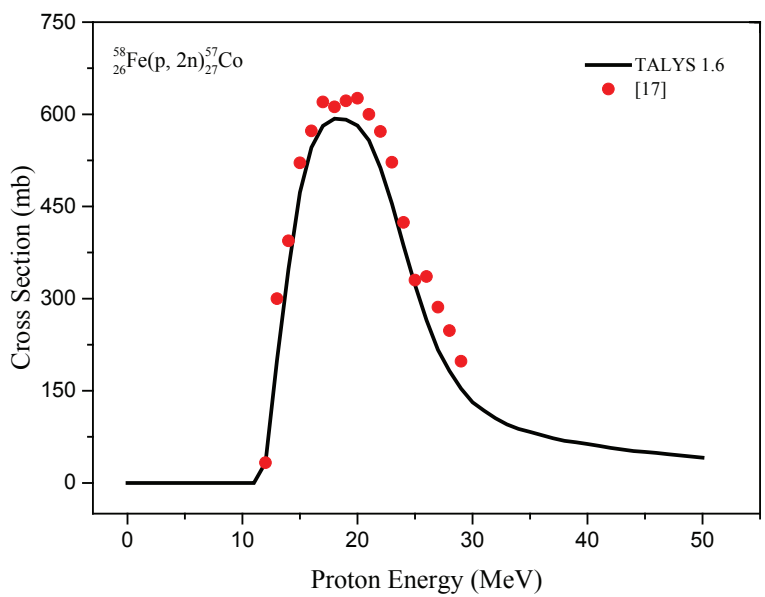

Figure 2: Excitation function of the ${ }^{58} \mathrm{Fe}(\mathrm{p}, 2 \mathrm{n}){ }^{57} \mathrm{Co}$ nuclear reaction.

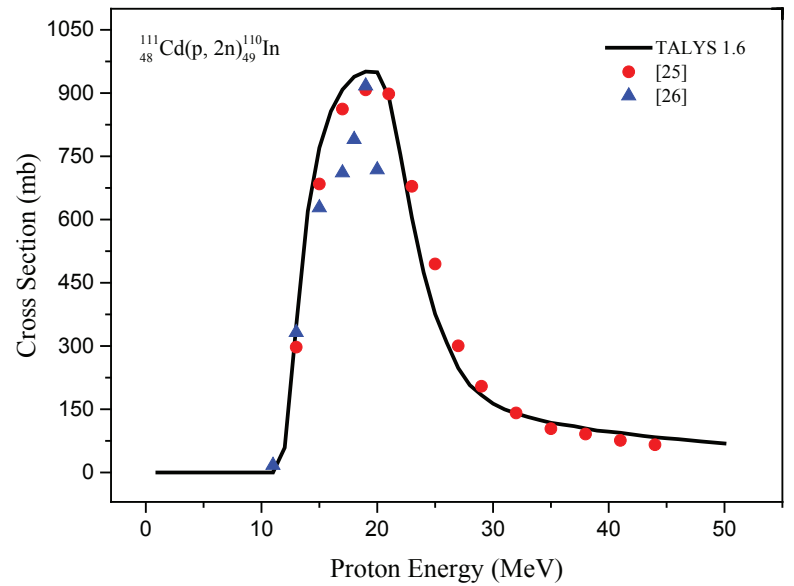

Figure 3: Excitation function of the ${ }^{111} \mathrm{Cd}(\mathrm{p}, 2 \mathrm{n})^{110} \mathrm{In}$ nuclear reaction. 


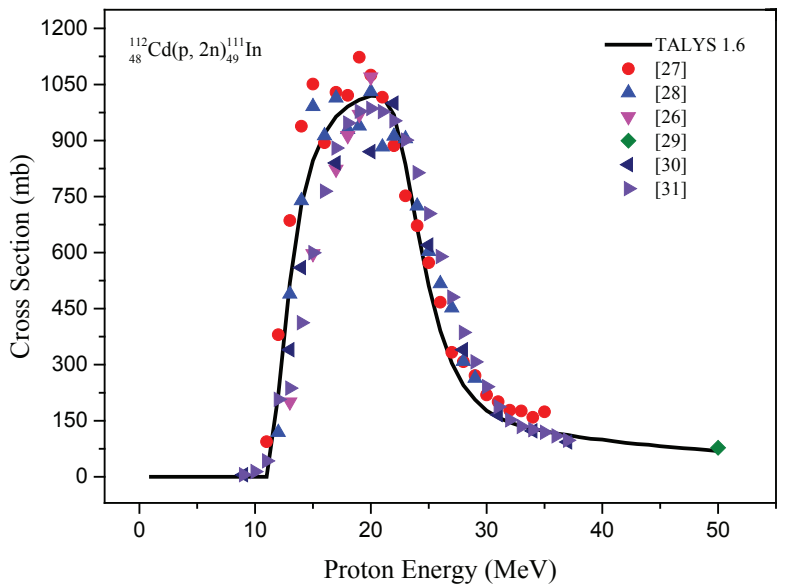

Figure 4: Excitation function of the ${ }^{112} \mathrm{Cd}(\mathrm{p}, 2 \mathrm{2})^{111} \mathrm{In}$ nuclear reaction.

availability high quality of PET technology there is role in thyroid cancer imaging, as well as promising applications in neurology and oncology. Because of ${ }^{124} \mathrm{I}$ long half -life ( $4.18 \mathrm{~d}$ ), stability, and radiation emissions, this permitted to use in several applications in oncological and nononcological fields.

${ }^{125} \mathrm{I}$ is a low energy gamma emitter, it can be used for a variety of applications. ${ }^{125} \mathrm{I}$ is a versatile isotope that is becoming more diffuse in diagnostic and therapeutic applications. It is also included in in-vitro diagnostic kits (radioimmunoassay), as a source for bone densitometry devices and therapeutic seed used in prostate cancer treatment. It is used in radiation therapy to treat brain tumors, Lung Cancer, uveal melanomas, Eye Plaques [10,32-34]. To discuss the theoretical calculated results of the excitation functions of two iodine radioisotopes ${ }^{124} \mathrm{I}$ and ${ }^{125} \mathrm{I}$ mentioned above, via ${ }^{125} \mathrm{Te}(\mathrm{p}, 2 \mathrm{n})^{124} \mathrm{I}$, ${ }^{126} \mathrm{Te}(\mathrm{p}, 2 \mathrm{n})^{125} \mathrm{I}$ reactions, we present Figures 5 and 6 that show the comparison of the current calculated results for the excitation functions by using TALYS 1.6 with the experimental data from EXFOR library. The energy range of proton was selected between 10 and $90 \mathrm{MeV}$ in Figure 5 for ${ }^{125} \mathrm{Te}(\mathrm{p}, 2 \mathrm{n})^{124} \mathrm{I}$ reaction and between 10 and 100 in Figure $6{ }^{126} \mathrm{Te}(\mathrm{p}, 2 \mathrm{n})^{125} \mathrm{I}$ reaction to make a comparison with the experimental data reported in the literature. The most appropriate production range for ${ }^{124} \mathrm{I}$ and ${ }^{125} \mathrm{I}$ using ${ }^{125} \mathrm{Te}(\mathrm{p}, 2 \mathrm{n}){ }^{124} \mathrm{I},{ }^{126} \mathrm{Te}(\mathrm{p}, 2 \mathrm{n}){ }^{125} \mathrm{I}$ nuclear reaction is $12-30 \mathrm{MeV}$.

\subsection{Gallium Radioisotope Production}

${ }^{67} \mathrm{Ga}$ is used to find and treat certain diseases or to study the function of the body's organs. ${ }^{67} \mathrm{Ga}$ used in the imaging of lymphoma tumours, useful for detection of inflammatory disease especially of soft tissue, and sites of inflammation

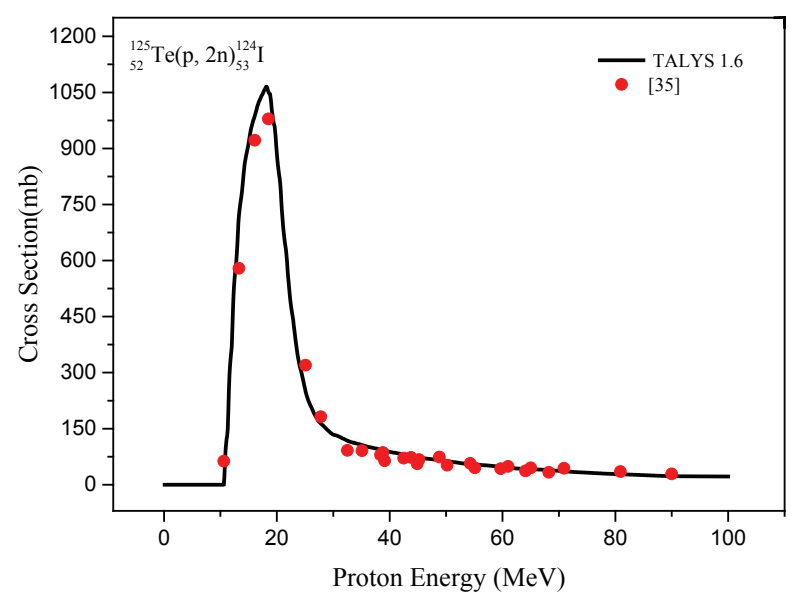

Figure 5: Excitation function of the ${ }^{125} \mathrm{Te}(\mathrm{p}, 2 \mathrm{n})^{124} \mathrm{I}$ nuclear reaction.

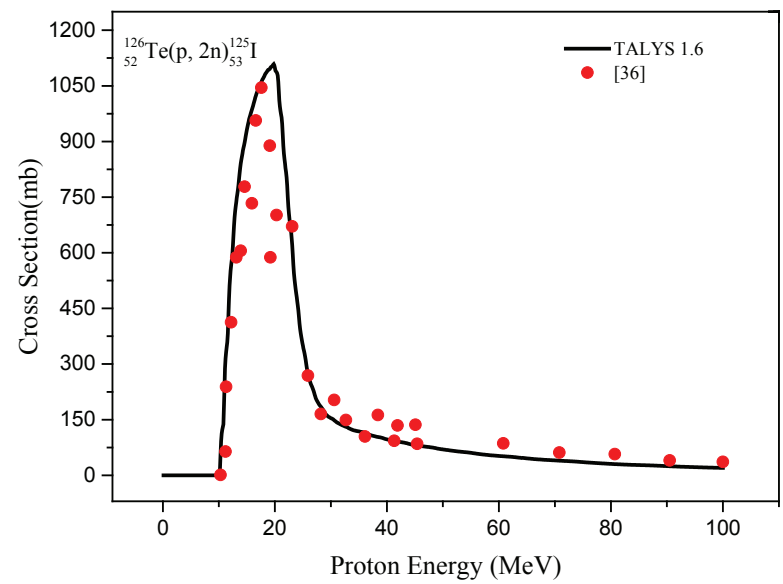

Figure 6: Excitation function of the ${ }^{126} \mathrm{Te}(\mathrm{p}, 2 \mathrm{n})^{125}$ I nuclear reaction.

such as chronic infections and abscess. and also septic arthritis, and cellulitis, spinal osteomyelitis, ulcerative colitis, interstitial nephritis, in addition to localization of source of fever in cases of fever of unknown origin (FUO) and other diseases.

Localization of inflammatory foci in postoperative patients considered as one of the most uses of ${ }^{67} \mathrm{Ga}$, also in patients who present with fever of undetermined origin. On the other hand, Gallium-67 citrate is used to detect types of cancer such as Hodgkin's disease, lymphoma, bronchial carcinoma and lung cancer. Excitation functions of the proton-induced at energies up to 100 $\mathrm{MeV}$ activities on ${ }^{68} \mathrm{Zn}$ via reaction ${ }^{68} \mathrm{Zn}(\mathrm{p}, 2 \mathrm{n}){ }^{67} \mathrm{Ga}$ were calculated by TALYS 1.6 code to obtained radioisotopes ${ }^{67} \mathrm{Ga}$ [37-40] The calculated and experimental excitation function of ${ }^{68} \mathrm{Zn}(\mathrm{p}, 2 \mathrm{n}){ }^{67} \mathrm{Ga}$ reaction have been plotted in Figure 7. The most appropriate production range for ${ }^{67} \mathrm{Ga}$ using ${ }^{68} \mathrm{Zn}(\mathrm{p}, 2 \mathrm{n}){ }^{67} \mathrm{Ga}$ nuclear reaction is $12-28 \mathrm{MeV}$. 
Table 2: The mean (average) value, variance and standard deviation.

\begin{tabular}{llllll}
\hline Reactions & $\begin{array}{l}\text { Minimum } \\
\text { value }\end{array}$ & $\begin{array}{l}\text { Maximum } \\
\text { value }\end{array}$ & $\begin{array}{l}\text { Mean } \\
\text { value }\end{array}$ & variance & Standard deviation \\
\hline${ }^{56} \mathrm{Fe}(\mathrm{p}, 2 \mathrm{n}){ }^{55} \mathrm{Co}$ & 0 & 82.4297 & 16.32126 & 473.5014 & 20.91653 \\
${ }^{58} \mathrm{Fe}(\mathrm{p}, 2 \mathrm{n})^{57} \mathrm{Co}$ & 0 & 592.945 & 86.94197 & 24507.23 & 156.5478 \\
${ }^{111} \mathrm{Cd}(\mathrm{p}, 2 \mathrm{n}){ }^{110} \mathrm{In}$ & 0 & 951.152 & 194.6637 & 76993.74 & 277.4775 \\
$\left.{ }^{112} \mathrm{Cd}(\mathrm{p}, 2 \mathrm{n})\right)^{111} \mathrm{n}$ & 0 & 1019.87 & 222.8956 & 100455.7 & 316.9475 \\
${ }^{125} \mathrm{Te}(\mathrm{p}, 2 \mathrm{n}){ }^{124} \mathrm{I}$ & 0 & 1064.95 & 158.7883 & 71113.42 & 266.671 \\
${ }^{126} \mathrm{Te}(\mathrm{p}, 2 \mathrm{n}){ }^{125}$ & 0 & 1108.63 & 166.7622 & 81499.32 & 285.4809 \\
${ }^{68} \mathrm{Zn}(\mathrm{p}, 2 \mathrm{n}){ }^{67} \mathrm{Ga}$ & 0 & 689.042 & 106.3798 & 34017.69 & 184.4388 \\
\hline
\end{tabular}

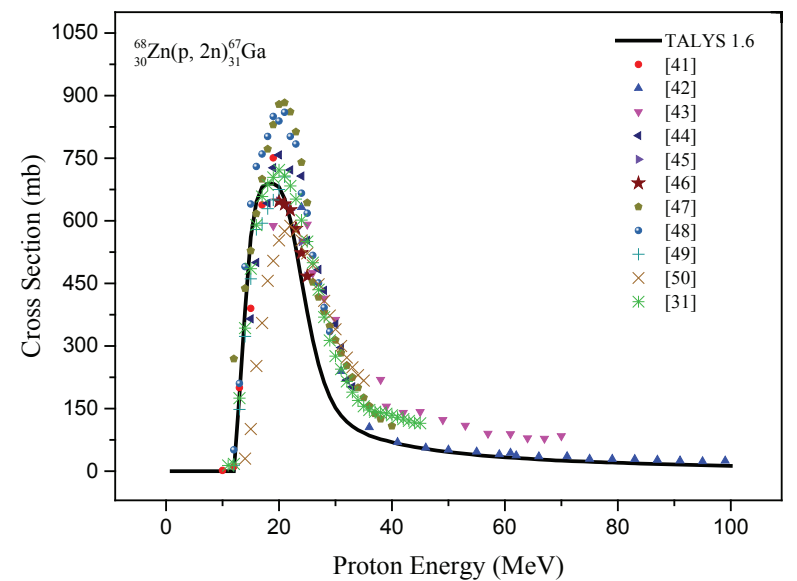

Figure 7: Excitation function of the ${ }^{68} \mathrm{Zn}(\mathrm{p}, 2 \mathrm{n})^{67} \mathrm{Ga}$ nuclear reaction.

\section{Standard Deviation}

Standard deviation is the measure of spread in the statistics of a set of data from its mean. For the excitation function obtained in the current work for the radioisotopes used in nuclear medicine, ${ }^{55} \mathrm{Co},{ }^{57} \mathrm{Co},{ }^{110} \mathrm{In},{ }^{111} \mathrm{In},{ }^{124} \mathrm{I},{ }^{125} \mathrm{I}$ and ${ }^{67} \mathrm{Ga}$ via proton induced, the standard deviation were calculated by using the formula:

$$
s=\sqrt{\frac{\sum(X-\bar{X})^{2}}{n-1}}
$$

Where $\mathrm{x}$ is one of value of data, $\overline{\mathbf{x}}$ is the average of all values in data, $\mathrm{n}$ is the number of values in the data. The results of the Standard deviation are listed in Table 2.

\section{Conclusion}

In this work, the calculated excitation functions of $\left.\quad{ }^{56} \mathrm{Fe}(\mathrm{p}, 2 \mathrm{n})\right)^{55} \mathrm{Co}, \quad{ }^{58} \mathrm{Fe}(\mathrm{p}, 2 \mathrm{n}){ }^{57} \mathrm{Co}, \quad{ }^{111} \mathrm{Cd}(\mathrm{p}, 2 \mathrm{n}){ }^{110} \mathrm{In}$,
${ }^{112} \mathrm{Cd}(\mathrm{p}, 2 \mathrm{n}){ }^{111} \mathrm{In},{ }^{125} \mathrm{Te}(\mathrm{p}, 2 \mathrm{n}){ }^{124} \mathrm{I},{ }^{126} \mathrm{Te}(\mathrm{p}, 2 \mathrm{n}){ }^{125} \mathrm{I},{ }^{68} \mathrm{Zn}(\mathrm{p}, 2 \mathrm{n}){ }^{67} \mathrm{Ga}$ reactions have been carried out using nuclear reaction model TALYS 1.6. The calculations are in a good agreement with the experimental results, which were all were taken from the EXFOR library, except as seen in Figure 7, some of the experimental data is higher in the peaked region by about $25 \%$, this could be due to the older experimental technique used in this measurement. The resulting radioisotopes ${ }^{55} \mathrm{Co},{ }^{57} \mathrm{Co},{ }^{110} \mathrm{In},{ }^{111} \mathrm{In},{ }^{124} \mathrm{I},{ }^{125} \mathrm{I}$ and ${ }^{67} \mathrm{Ga}$ have important and wide applications in nuclear medicine, and according to the results were shown in Figures 1-7 the small extent of energy so it can be produced by small sized cyclotrons.

Conflict of interest: Authors state no conflict of interest.

\section{References}

[1] Aydin, A., Şarer, B., Tel, E., New calculation of excitation functions of proton-induced reactions in some medical isotopes of $\mathrm{Cu}, \mathrm{Zn}$ and $\mathrm{Ga}$, Applied Radiation and Isotopes, 2007, 65, 365-370.

[2] Kilinç, F., Karpuz, N., Çetin, B., Calculation of the (p, n) Reaction Cross Section of Radionuclides Used for PET Applications, Acta Physica Polonica A, 2016, 130(1), 318-319.

[3] Karpuz Demir, N., Çetin, B., Akkurt, İ., Noori, S.S., Calculations of Double Differential Cross Sections on ${ }^{56} \mathrm{Fe},{ }^{63} \mathrm{Cu}$ and ${ }^{90} \mathrm{Zr}$ Neutron Emission in Proton Induced Reactions, Acta Physica Polonica A, 2017, 132(3-II), 1181-1185.

[4] Mohamed, M. B., Study of the excitation function for some cyclotron produced radionuclides, $\mathrm{PhD}$ thesis, Mansoura University, Egypt, 2006.

[5] IAEA, Production of Long Lived Parent Radionuclides for Generators: ${ }^{68} \mathrm{Ge},{ }^{82} \mathrm{Sr},{ }^{90} \mathrm{Sr}$ and ${ }^{188} \mathrm{~W}$, IAEA radioisotopes and radiopharmaceuticals series No. 2, 2010, STI/PUB/1436, VIENNA.

[6] Noori, S. S., Akkurt, I., Karpuz, N., Comparison of Excitation Functions of Longer and Shorter Lived Radionuclides, Acta Physica Polonica A, 2017, 132 (3-II), 1186-1188.

[7] Koning, A., Hilaire, S., Goriely, S., TALYS-1.6 A Nuclear Reaction Program, User Manual, 2013, NRG, the Netherlands. 
[8] EXFOR/CSISRS, Experimental Nuclear Reaction Data File, 2017, Brookhaven National Laboratory, National Nuclear Data Center.

[9] Issa, S. A. A. M., Cross Section for Residual Nuclide Production by Proton-Induced Reaction with Heavy Target Elements at Medium Energies, PhD thesis, Al-Azhar University, Assiut, Egypt, 2009.

[10] Artun, O., Aytekin, H., Calculation of excitation functions of proton, alpha and deuteron induced reactions for production of medical radioisotopes ${ }^{122-125}$, Nuclear Instruments and Methods in Physics Research B, 2015, 345, 1-8.

[11] IAEA, Cyclotron Produced Radionuclides: Physical Characteristics and Production Methods Technical, Technical Reports Series No. 468, 2009, STI/DOC/010/468, Vienna, Austria.

[12] Spellerberg, S., Reimer, P., Blessing, G., Coenen, H. H., Qaim, S. M., Production of ${ }^{55} \mathrm{Co}$ and ${ }^{57} \mathrm{Co}$ via Proton Induced Reactions on Highly Enriched ${ }^{58} \mathrm{Ni}$, Applied Radiation and Isotopes, 1998, 49(12), 1519-1522.

[13] Mirzaii, M., Kakavand, T., Talebi, M., Rajabifar, S., Electrodeposition iron target for the cyclotron production of ${ }^{55} \mathrm{Co}$ in labeling proteins, Journal of Radioanalytical and Nuclear Chemistry, 2012, 292(1), 261-267.

[14] Usman, A. R., Khandaker, M. U., Haba, H., Murakami, M., Otuka, N., Measurements of deuteron-induced reaction crosssections on natural nickel up to $24 \mathrm{MeV}$, Nuclear Instruments and Methods in Physics Research B, 2016, 368, 112-119.

[15] Mastren, T., Marquez, B. V., Sultan, D. E., Bollinger, E., Eisenbeis, P., Voller, T., Lapi, S. E., Cyclotron production of high specific activity ${ }^{55} \mathrm{Co}$ and in vivo evaluation of the stability of ${ }^{55} \mathrm{Co}$ metal-chelate-peptide complexes, HHS Public Access, Author manuscript, 2015, 14, 526-533.

[16] Wenron, Z., Hanlin, L., Weixiang, Y., Measurement of cross sections by bombarding Fe with protons up to $19 \mathrm{MeV}$, Chinese Journal of Nuclear Physics, 1993, 15(4), 337- 340.

[17] Levkovski, V. N., Cross sections of medium mass nuclide activation $(A=40-100)$ by medium energy protons and alphaparticles ( $E=10-50 \mathrm{MeV}$ ), Book: Act. Cs. By Protons and Alphas, Moscow, 1991.

[18] Jenkins, I. L., Wain, A. G., Excitation Functions for the Bombardment of ${ }^{56} \mathrm{Fe}$ with Protons, Journal of Inorganic and Nuclear Chemistry, 1970, 32(5), 1419-1425.

[19] Lagunas-Solar, M. C., Jungerman, J. A., Cyclotron Production of Carrier-Free Cobalt-55, a New Positron Emitting Label for Bleomycin, The International Journal of Applied Radiation and Isotopes, 1979, 30, 25-32.

[20] Fakhari, F. E., Separation and Purification of ${ }^{111}$ In from Irradiated Cadmium Targets by Solid Phase Extraction (SPE) Method for Medical Applications, PhD thesis, Philipps-University Marburg, The Department of Chemistry, 2006.

[21] Mostafa, M., El-Sadek, A. A., El-Said, H., El-Amir, M. A., ${ }^{99} \mathrm{Mo} /$ ${ }^{99} \mathrm{mTc}-{ }^{113} \mathrm{Sn} /{ }^{113 \mathrm{~m}} \mathrm{In}$ Dual Radioisotope Generator Based on 6-Tungstocerate(IV) Column Matrix, Journal of Nuclear and Radiochemical Sciences, 2009, 10(1), 1-12.

[22] Al-Abyad, M., Proton induced nuclear reactions on cadmium up $17 \mathrm{MeV}$, Third International Conference on Radiation Sciences and Applications (12 - 16 November 2012, Hurghada, Egypt) Cairo 13759, Egypt, 2012, 353-363.

[23] Khandaker, M. U., Kim, K., Lee, M., Kim, K. S., Lee, Y. S., Cho, Y. O., Lee, Y. O., Kim, G., Experimental Study of Proton Induced Cross-sections on Natural Cadmium Leading to the
Production of ${ }^{111} \mathrm{In}$ Radionuclide, Journal of Nuclear Science and Technology, 2008, 45, 237-240.

[24] Kilinç, F., Karpuz, N., Çetina, B., Theoretical Cross-Section Calculation of In-111, Tc-99m, Co-57 Radioisotopes Used for Kidney Imaging, Acta Physica Polonica A, 2016, 130(1), 311-312.

[25] Marten, M., Schuring, A., Scobel, W., Probst, H. J., Preequilibrium Neutron Emission in ${ }^{109} \mathrm{Ag}\left({ }^{3} \mathrm{He}, \mathrm{xn}\right)$ and ${ }^{111} \mathrm{Cd}(\mathrm{p}, \mathrm{xn})$ Reactions, Zeitschrift für Physik A Atoms and Nuclei, 1985, 322(1), 93-103.

[26] Skakun, E. A., Klyucharev, A. P., Rakivnenko, Y. N., Romanii, I. A., Excitation Functions of (p,n)- and ( $p, 2 n)$-Reactions on Cadmium Isotopes, Izvestiya Akademii Nauk SSSR, Seriya Fizicheskaya, 1975, 39(1), 24-30.

[27] Hermanne, A., Adam-Rebeles, R., Van den Winkel, P., Tarkanyi, F., Takacs, S., Production of ${ }^{111} \mathrm{In}$ and ${ }^{114 \mathrm{~m}} \mathrm{In}$ by proton induced reactions: an update on excitation functions, chemical separation - purification and recovery of target material, Radiochimica Acta, 2014, 102(12), 1111-1126.

[28] Tárkányi, F., Szelecsényi, F., Kopecký, P., Molnár, T., Andó, L., Mikecz, P., Tóth, GY., Rydl, A., Cross Sections of Proton Induced Nuclear Reactions on Enriched ${ }^{111} \mathrm{Cd}$ and ${ }^{112} \mathrm{Cd}$ for the Production of ${ }^{111}$ In for Use in Nuclear Medicine, Applied Radiation and Isotopes, 1994, 45(2), 239-249.

[29] Nieckarz, W. J., Caretto, A. A., Production of ${ }^{111} \mathrm{In}$ and ${ }^{114 \mathrm{~m}} \mathrm{In}$ from the Separated Isotopes of Cadmium Using 70- to 400-MeV Protons, Physical Review, 1969, 178, 1887.

[30] Otozai, K., Kume, S., Mito, A., Okamura, H., Tsujino, R., Kanchiku, Y., Katoh, T., Gotoh, H., Excitation Functions for the Reactions Induced by Protons on Cd up to $37 \mathrm{MeV}$, Nuclear Physics, 1966, 80(2), 335-348.

[31] Takács, S., Tárkányi, F., Hermanne, A., Validation and upgrading of the recommended cross-section data of charged particle reactions: Gamma emitter radioisotopes, Nuclear Instruments and Methods in Physics Research Section B, 2005, 240(4), 790-802.

[32] Cascini, G. L., Asabella, A. N., Notaristefano, A., Restuccia, A., Ferrari, C., Rubini, D., Altini, C., Rubini, G., ${ }^{124}$ lodine: A LongerLife Positron Emitter Isotope-NewOpportunities in Molecular Imaging, Hindawi Publishing Corporation, BioMed Research International, 2014, 2014(1), 1-7.

[33] Niu, L., Zhou, L., Xu, K., Mu, F., Combination of cryosurgery and lodine-125 seeds brachytherapy for lung cancer, Journal of Thoracic Disease, 2012, 4(5), 504-507.

[34] Demir, B., Çapalı, V., Sarpün, I. H., Kaplan, A., Production Cross-Section Calculations of Medical ${ }^{125}$ I Radionuclide Using $\alpha$, $d$ and $\gamma$ Induced Reactions, SDU Journal of Science (E-Journal), 2015, 10, 116-121.

[35] Hohn, A., Nortier, F. M., Scholten, B., van der Walt, T. N., Coenen, H. H., Qaim, S. M., Excitation Functions of ${ }^{125} \mathrm{Te}(\mathrm{p}, \mathrm{xn})$ Reactions from Their Respective Thresholds up to $100 \mathrm{MeV}$ with Special Reference to the Production of ${ }^{124}$, Applied Radiation and Isotopes, 2001, 55, 149-156.

[36] Scholten, B., Hassan, K .F., Saleh, Z. A., Coenen, H. H., Qaim, S. M., Comparative studies on the production of the medically important radionuclide ${ }^{124}$ I via $\mathrm{p}$-, $d$-, $3 \mathrm{He}$ - and $\alpha$-particle induced reactions, Conference on Nuclear Data for Science and Technology, 2007, 2, 1359-1361.

[37] Morton, K. A., Jarboe, J., Burke, E. M., Gallium-67 Imaging in Lymphoma: Tricks of the Trade, Journal Nuclear Medicine Technology, 2000, 28(4), 221-232. 
[38] Staab, E. V., McCartney, W. H., Role of gallium 67 in inflammatory disease, Seminars in Nuclear Medicine, 1978, 8(3), 219-34.

[39] Avagyan, R., Avetisyan, R., Bazoyan, G., Hakobyan, M., Kerobyan, I., Estimation of the Productivity Isotope ${ }^{67} \mathrm{Ga}$ on Cyclotron C18 for Nuclear Medicine, Universal Journal of Applied Science, 2014, 2(7), 221-224.

[40] Nasrabadi, M. N., Sepiani, M., Study of components and statistical reaction mechanism in simulation of nuclear process for optimized production of ${ }^{64} \mathrm{Cu}$ and ${ }^{67} \mathrm{Ga}$ medical radioisotopes using TALYS, EMPIRE and LISE++ nuclear reaction and evaporation codes, American Institute of Physics, 2015, AIP Conference Proceedings 1653, 020076-1-020076-6.

[41] Szelecsenyi, F., Kovacs, Z., Nagatsu, K., Fukumura, K., Suzuki, K., Mukai, K., Investigation of direct production of ${ }^{68} \mathrm{Ga}$ with low energy multiparticle accelerator, Radiochimica Acta, 2012, 100(1), 5-11.

[42] Szelecsenyi, F., Steyn, G. F., Kovacs, Z., Van der Walt, T. N., Suzuki, K., Okada, K., Mukai, K., New cross-section data for the ${ }^{66} \mathrm{Zn}(\mathrm{p}, \mathrm{n}){ }^{66} \mathrm{Ga},{ }^{68} \mathrm{Zn}(\mathrm{p}, 3 \mathrm{n}){ }^{66} \mathrm{Ga}$, nat $\mathrm{Zn}(\mathrm{p}, \mathrm{x}){ }^{66} \mathrm{Ga},{ }^{68} \mathrm{Zn}(\mathrm{p}, 2 \mathrm{n}){ }^{67} \mathrm{Ga}$ and ${ }^{\text {nat }} \mathrm{Zn}(\mathrm{p}, \mathrm{x})^{67} \mathrm{G}$ a nuclear reactions up to $100 \mathrm{MeV}$, Nuclear Instruments and Methods in Physics Research Section B, 2005, 234(4), 375-386.

[43] Stoll, T., Kastleiner, S., Shubin, Yu. N., Coenen, H. H., Qaim, S. M., Excitation functions of proton induced reactions on ${ }^{68} \mathrm{Zn}$ from threshold up to $71 \mathrm{MeV}$, with specific reference to the production of ${ }^{67} \mathrm{Cu}$, Radiochimica Acta, 2002, 90(6), 309-313.

[44] Hermanne, A., Szelecsenyi, F., Sonck, M., Takacs, S., Tarkanyi, F., Van den Winkel, P., New Cross Section Data on ${ }^{68} \mathrm{Zn}(\mathrm{p}, 2 \mathrm{n}){ }^{67} \mathrm{Ga}$ and ${ }^{\text {nat }} \mathrm{Zn}(\mathrm{p}, \mathrm{xn}){ }^{67} \mathrm{Ga}$ Nuclear Reactions for the Development of a reference data base, Journal of Radioanalytical and Nuclear Chemistry, 1999, 240(2), 623-630.
[45] Szelecsenyi, F., Boothe, T. E., Takacs, S., F. Tarkanyi, E. Tavano, Evaluated cross section and thick target yield data bases of $\mathrm{Zn}$ $+\mathrm{p}$ processes for practical applications, Applied Radiation and Isotopes, 1998, 49(8), 1005-1032.

[46] Szelecsenyi, F., Boothe, T. E., Tavano, E., Plitnikas, M. E., Feijoo, Y., Takacs, S., Tarkanyi, F., Szucs, Z., New cross section data for ${ }^{66-67-68} \mathrm{Zn}+\mathrm{p}$ reactions up to $26 \mathrm{MeV}$, Nuclear Data for Science and Technology, Gatlinburg 1994, 393.

[47] Hermanne, A., Walravens, N., Cicchelli, O., Optimization of isotope production by cross section determination, Nuclear Data for Science and Technology, Juelich 1991, 616-618.

[48] Tarkanyi, F., Szelecsenyi, F., Kovacs, Z., Sudar, S., Excitation functions of proton induced nuclear reactions on enriched ${ }^{66} \mathrm{Zn},{ }^{67} \mathrm{Zn}$ and ${ }^{68} \mathrm{Zn}$ production of ${ }^{67} \mathrm{Ga}$ and ${ }^{66} \mathrm{Ga}$, Radiochimica Acta, 1990, 50(1-2), 19-26.

[49] Little, F. E., Lagunas-Solar, M.C., Cyclotron production of ${ }^{67} \mathrm{Ga}$. cross sections and thick-target yields for the ${ }^{67} \mathrm{Zn}(\mathrm{p}, \mathrm{n})$ and ${ }^{68} \mathrm{Zn}(\mathrm{p}, 2 \mathrm{n})$ reactions, The International Journal of Applied Radiation and Isotopes, 1983, 34(3), 631-637.

[50] Takacs, S., Tarkanyi, F., Hermanne, A., Validation and upgrading of the recommended cross-section data of charged particle reactions: Gamma emitter radioisotopes, Nuclear Instruments and Methods in Physics Research Section B, 2005, 240(4), 790-802. 